\title{
Role of Carnosine and Melatonin in Ameliorating Cardiotoxicity of Titanium Dioxide Nanoparticles in the Rats
}

\author{
Nouf Al-Rasheed ${ }^{1}$, Laila Faddah ${ }^{1}$, Hanan Ibrahim ${ }^{2,3^{*}}$, Azza M Mohamed ${ }^{2,4}$, Nawal Al- \\ Rasheed $^{1}$ and Nayira Abdelbaky ${ }^{1}$ \\ ${ }^{1}$ Faculty of Pharmacy-Pharmacology Department; King Saudi University; Riyadh - Saudi Arabia. ${ }^{2}$ Faculty of \\ Science- Al Faisalia Campus- Biochemistry Department; King Abdulaziz University; Jeddah - Saudi Arabia. \\ ${ }^{3}$ Faculty of Medicine-Medical Biochemistry Department; Alexandria University; Alexandria - Egypt. ${ }^{4}$ Theraputic \\ Chemistry Department; National Research Center; Dokki - Egypt
}

\begin{abstract}
The aim of this work was to study the possible cardiotoxicity of two different doses of $50 \mathrm{~nm}$ nano titanium dioxide $\left(\mathrm{n}-\mathrm{TiO}_{2}\right)$ and the possible modulating effects of the use of two natural antioxidants carnosine and melatonin. The results showed that $\mathrm{TiO}_{2}$. NPs produced deleterious effects on rat cardiac tissue as confirmed by the increased levels of serum myoglobin, troponin-T and CK-MB. Increased levels of serum Inflammatory markers represented by the tumor necrosis factor alpha (TNF- $\alpha)$ and Interleukin-6 (IL-6) was also noticed. Caspase3 and IGg were elevated compared to the control group in a dose dependant manner. treatment of the rats with Carnosine or melatonin. along with $\mathrm{TiO}_{2}$. NPs administration significantly improved most of the elevated biochemical markers. It was concluded that the use of Carnosine or melatonin could play a beneficial role against deleterious effects of $\mathrm{TiO}_{2-} \mathrm{NPS}$
\end{abstract}

Key words: Titanium dioxide nanoparticles, cardiotoxicity, carnosine, melatonin

\section{INTRODUCTION}

Naturally occurring titanium dioxide, also known as titania, has a wide scale of applications such as in paints, sunscreen or even food colouring (Robertson et al. 2010; Saber et al. 2012). It was thought that $\mathrm{TiO}_{2^{-}}$NPs were non-toxic mineral (Sager et al. 2008). However, many studies suggested that titanium dioxide nanoparticles could be more toxic than their original materials (Long et al. 2007; Zhao Jet al. 2009; Zhao Jet al. 2011; Magaye and Zhao 2012; Liu K et al. 2013). The exposure to nanoparticle can be either accidentally due to occupational exposure, or intentionally through different routs such as nose by inhalation, mouth by ingestion, skin contact or intravenous injection (Zhu et al. 2012; Khan and Maskat 2014). Owing to their tiny size, NPs can get an access to many biological structures, interacting with molecules such as proteins, lipids and nucleic acids, which may, in turn, interfere with their normal function, damage the subcellular organelles and cause cell death (Buzea et al. 2007; Kang et al. 2008; Park et al. 2008; Zhao and Castranova 2011; Zhu et al. 2012; Tay 2014). There are evidences showing that $\mathrm{TiO} 2$-NPs may induce the cardiotoxicity (Jawad et al. 2011) as well as toxicity of the circulatory system. It was found that red blood cells exposed to $\mathrm{TiO}_{2}-\mathrm{NPs}$ showed abnormal sedimentation,

*Author for correspondence: hkai1960@ gmail.com 
hemagglutination and hemolysis. Studies on animal models and in vitro experiments involving various cell lines have further proved the cytotoxicity of $\mathrm{TiO}_{2^{-}}$NPs, including the inflammation of many organs according to their rout of entry, induction of chromatin condensation, nuclear fragmentation, caspase activation, and even apoptosis (Kang et al. 2008; Zhu et al. 2012). The cytotoxicity of $\mathrm{TiO}_{2-} \mathrm{NPs}$ depend on their physical and chemical properties, especialy their size, as the smaller the particles, the more damage they cause (Sohaebuddin et al. 2010). It was found that $\mathrm{TiO}_{2}$ material catalyzed the water-splitting reaction, producing hydroxyl radicals (Varghese 2009; Mallik et al. 2011). ROS generation in $\mathrm{TiO}_{2}$-NPs- treated cells was increased according to the increase in its concentration, but ROS was decreased at a higher concentration due to the decrease in cell viability, resulting in fewer viable cells to measure ROS levels (Mallik et al. 2011). L-carnosine, a dipeptide made up of $\beta$ alanine and L-histidine was studied first in 1980s by Boldyrev et al. (2012). Later on, antioxidant activity of carnosine was proved, including the antioxidant mechanisms involving its ability to chelate the metal ions, and scavenging reactive oxygen species (ROS) and peroxyl radicals. Many in vitro and in vivo studies have proved the role of carnosine in preventing the formation of advanced lipoxidation endproducts (ALEs) and advanced glycoxidation endproducts (AGEs) that are accused in the pathogenesis of aging and in the diseases based on the oxidative sress such as diabetes, atherosclerosis, and Alzheimer's disease (Boldyrev et al. 2013).

Melatonin is a naturally occurring compound that has an antioxidant effect as it is a potant free radical recipient and can inhibit the formation of lipid peroxides, thus, guarding against oxidative stress. Also, it can oppose the oxidative stress in mitochondrial and the cyanide induced-inhibition of ATP by increasing ATP synthesis. It is called as a suicidal antioxidant, as it is consumed during its action (Galano 2011; Athanassiou 2013). It is suggested that melatonin has a role in modulating several physiological processes, including the control of blood pressure, and tumor growth (Abdelkarem and Faddah 2013). Melatonin, a hormone secreted from the pineal body is involved in the light-dark cycle and is also involved in the regulation of the immune system. Melatonin may be involved in cancer prevention through a role in conservation DNA integrity (Galano 2011; Aversa 2012; Gitto 2012).

The current work aimed to detect the possible toxic effects of low dose $(60 \mathrm{mg} / \mathrm{kg})$ as well as high dose $(1 \mathrm{~g} / \mathrm{kg}) 50 \mathrm{~nm} \mathrm{n}-\mathrm{TiO}_{2}$ on cardiac tissues of rats. The study was also conducted to determine whether natural antioxidants, such as carnosine and melatonin, could ameliorate the hazardous effects of $50 \mathrm{~nm} \mathrm{n-} \mathrm{TiO}_{2}$.

\section{MATERIAL AND METHODS}

\section{Chemicals}

All the chemicals used in the study were products of Sigma and Merck companies of high analytical grade. The n- $\mathrm{TiO}_{2}(50 \mathrm{~nm})$ powders were purchased from Sigma Co.( USA).

\section{Experimental Animals}

Animals were used with the compliance of the local ethics committee, involving 70 male albino rats (120-150 g), which were supplied by the Experimental Animal Center, King Saud University. The animals were housed in a standard housing conditions of humidity, temperature and light/dark cycle. They were provided with the commercial rat pellet diet and deionized water $a d$ libitum. After one week of acclimation, the rats were kept fasting overnight before the treatment. $\mathrm{TiO}_{2}$ was administered using two doses (600 $\mathrm{mg} / \mathrm{Kg}$ body and $1.0 \mathrm{~g} / \mathrm{Kg}$ body weight/day) according to the OECD procedure (1992). According to the dose of $\mathrm{TiO}_{2}-\mathrm{NPs}$, the rats were divided into two classes. Class I comprised four groups of 10 rats each as follows: Group1: Normal healthy animals; Groups 2-4 of animals administered orally $600 \mathrm{mg} / \mathrm{Kg}$ body weight/day $\mathrm{TiO}_{2}$-NPs for five consecutive days and divided as follow: Group 2: $\mathrm{TiO}_{2}-\mathrm{NPs}$ intoxicated animals; Group 3: $\mathrm{TiO}_{2}$-NPs intoxicated animals with the addition of $200 \mathrm{mg} / \mathrm{Kg}$ carnosine; Group 4: $\mathrm{TiO}_{2^{-}}$ NPs intoxicated animals with the addition of 200 $\mathrm{mg} / \mathrm{Kg}$ melatonin. Class II consisted of three groups; Groups 5-7 of ten rats each. In this class, TiO2-NPs were administered orally at $1.0 \mathrm{~g} / \mathrm{Kg}$ body weight/ day for five consecutive days. Animals were divided as follow: Group 5: $\mathrm{TiO}_{2-}$ NPs intoxicated animals for 5 consecutive days; Group 6: $\mathrm{TiO}_{2^{-}} \mathrm{NPs}$ intoxicated animals with addition of $200 \mathrm{mg} / \mathrm{Kg}$ carnosine; Group 7: $\mathrm{TiO}_{2^{-}}$ NPs intoxicated animals with addition of 200 $\mathrm{mg} / \mathrm{Kg}$ melatonin. 
$\mathrm{TiO}_{2}$-NPs were suspended in $1.0 \%$ Tween 80 and treated by ultrasonic vibration for $15 \mathrm{~min}$. The control group was given $1.0 \%$ Tween solution. Carnosine and melatonin were given orally for three weeks. After that, the rats of all the groups were kept fasting over-night. Then blood samples were collected from each rat in all the groups for serum separation by centrifugation at $3000 \mathrm{xg}$ for $10 \mathrm{~min}$ and used for biochemical tests. Rats of each group were sacrificed under ether anesthesia and the cardiac samples were collected, weighed, and washed using chilled saline solution. The cadiac tissue were minced and homogenized in ice-cold double distilled water to yield $10 \%$ homogenates. The homogenates were centrifuged at $4,000 \mathrm{rpm}$ at $4^{\circ} \mathrm{C}$ for $15 \mathrm{~min}$, and the supernatants were used for caspase- 3 assay.

\section{Biochemical Serum Analysis}

Serum were assayed for the cardiac function parameters myoglobin, troponin, and creatine kinase by using standard diagnostic kits. TNF- $\alpha$ was quantified using ELISA kit (Endogen, Woburn, MA). IL-6 was measured by ultrasensitive ELISA (Quantikine HS Human IL-6 Immunoassay; R\&D Systems, Minneapolis, MN) with an analytical $\mathrm{CV}$ of $6.3 \%$ and a detection level of $0.04 \mathrm{pg} / \mathrm{mL}$ (Hang L.1994). IgG level was measured in the serum using a sandwich enzyme linked immunosorbent assay (ELISA) (Sigma Chemical Co., St. Louis, MO).

\section{Biochemical Assay of Cardiac Tissue}

Caspase-3 activity assay was done according to Thornberry and Lazebnik (1998). The Comet assay or single cell gel electrophoresis (SCGE) was performed to estimate the DNA damage. The method included the unwinding DNA under alkaline conditions (Singh et al. 1988). The measures used to analyze the electrophoretic patterns were: tail length measured from the middle of the head to the end of the tail and relative DNA content in the tail.

\section{Statistical Analysis}

Data were statistically analyzed by comparing the values of different groups with the values of controls. Results are expressed as mean \pm Standard Deviation (SD). Significant differences among the values were analyzed using ANOVA test, followed by Bonferroni 's test post-ANOVA. Value of $p \leq 0.05$ was considered statistically significant.

\section{RESULTS}

Tables 1 and 2, respectively showed that $\mathrm{TiO}_{2-}$ NPs, either in low or in high repeated doses did not significantly affect either the final weight of rats or their heart weight or the heart/body weight ratio.

Table 1 - Effect of Carnosine and Melatonine on body weight, Heart weight, and Heart /body weigh \% with low dose of $\mathrm{n}-\mathrm{TiO}_{2}$

\begin{tabular}{|c|c|c|c|c|}
\hline & \multicolumn{2}{|c|}{ Body Weight (g) } & \multirow{2}{*}{ Heart Weight (g) } & \multirow{2}{*}{ Heart /Body Weigh \% } \\
\hline & Initial & Final & & \\
\hline Control & $226 \pm 32.32$ & $249 \pm 41.2$ & $1.19 \pm 0.08$ & $0.459 \pm 0.030$ \\
\hline $\mathrm{TiO}_{2}$-NPs & $236 \pm 19.41$ & $270.50 \pm 24.52$ & $0.95 \pm 0.13$ & $0.389 \pm 0.065$ \\
\hline Car & $235 \pm 5$ & $262.5 \pm 5.5$ & $1.1 \pm 0.1$ & $0.419 \pm 0.043$ \\
\hline Mel & $238.2 \pm 12.27$ & $262.8 \pm 19.66$ & $1.15 \pm 0.129$ & $0.437 \pm 0.046$ \\
\hline
\end{tabular}

Table 2 - Effect of Carnosine and Melatonine on body weight, Heart weight, and Heart /body weigh \% in intoxicated rats with high dose of $n-\mathrm{TiO}_{2}$.

\begin{tabular}{lllll}
\hline & \multicolumn{2}{c}{ Body Weight (g) } & Heart Weight (g) & Heart /Body Weigh \% \\
\hline $\mathrm{Control}$ & $212 \pm 15.58$ & $260.5 \pm 25.05$ & $1.19 \pm 0.08$ & $0.459 \pm 0.030$ \\
$\mathrm{TiO}_{2-} \mathrm{NPs}$ & $226 \pm 32.32$ & $249 \pm 41.20$ & $0.95 \pm 0.13$ & $0.389 \pm 0.065$ \\
$\mathrm{Car}$ & $242.67 \pm 6.66$ & $271 \pm 10.58$ & $1.35 \pm 0.06$ & $0.493 \pm 0.037$ \\
$\mathrm{Mel}$ & $238.2 \pm 12.27$ & $262.8 \pm 19.66$ & $1.03 \pm 0.13$ & $0.366 \pm 0.015$ \\
\hline
\end{tabular}

As regard the cardiac functions represented by myoglobin, troponinT and creatine kinase MB isozyme, both the low and high dose TiO2-NPs
(Tables 3 and 4, respectively) showed significant increase in the serum levels compared to the control ( $p \leq 0.0010$. Oral intake of carnosine or 
melatonin showed significant reduction in their serum levels compared to $\mathrm{TiO}_{2}$-NPs intoxicated the rats $(\leq 0.01)$; serum creatine kinase reduction was more prominant in the carnosine treated group than melatonin treated group, while myoglobin level of both carnosine and melatonin of the high dose of $\mathrm{TiO}_{2}$-NPs did not show any difference than the intoxicated rats.

Table 3 - Effect of Carnosine and Melatonine treatment on cardiac functions markers Myoglobin, Troponin-T and Creatine Kinase MB (CK MB) with low dose of $n-\mathrm{TiO}_{2}$

\begin{tabular}{llcl}
\hline Group & Myoglobin $(\mathbf{p g} / \mathbf{m l})$ & Troponin-T $(\mathbf{n g} / \mathbf{m l})$ & CK MB $(\mathbf{n g} / \mathbf{m l})$ \\
\hline Control & $31.16 \pm 2.38$ & $27.14 \pm 3.15$ & $2.46 \pm 0.11$ \\
$\mathrm{TiO}_{2-} \mathrm{NPs}$ & $40.8 \pm 2.07^{* * * a}$ & $38.1 \pm 3.07^{* * * a}$ & $3.71 \pm 0.11^{* * * a}$ \\
$\mathrm{Car}$ & $36.26 \pm 1.21^{* * a \mathrm{ab}}$ & $31.94 \pm 2.09^{* * a b}$ & $2.65 \pm 0.25^{* * * \mathrm{~b}}$ \\
$\mathrm{Mel}$ & $35.72 \pm 2.20^{* * \mathrm{ab}}$ & $33.12 \pm 1.90^{* * a b}$ & $2.98 \pm 0.08^{* \mathrm{abc}}$ \\
\hline
\end{tabular}

Values are expressed as mean \pm SD. $* * * p \leq 0.001, * * \mathrm{p} \leq 0.01),{ }^{*} \mathrm{p} \leq 0.05$, a: Compared to Control group, b: Compared to $\mathrm{n}-\mathrm{TiO} \mathrm{O}_{2}$ group, c: compared to Carnosine group.

Table 4 - Effect of Carnosine and Melatonine treatment on cardiac functions markers Myoglobin,Troponin-T and Creatine Kinase MB (CK MB) with high dose of $\mathrm{n}-\mathrm{TiO}_{2}$

\begin{tabular}{|c|c|c|c|}
\hline Group & Myoglobin (pg/mL) & Troponin-T (ng/mL) & CK MB (ng/mL) \\
\hline Control & $31.16 \pm 2.38$ & $27.14 \pm 3.15$ & $2.64 \pm 0.11$ \\
\hline $\mathrm{TiO}_{2-} \mathrm{NPs}$ & $46.68 \pm 2.79^{* * * a}$ & $41.18 \pm 2.23^{* * * a}$ & $3.81 \pm 0.12^{* * * a}$ \\
\hline Car & $46.1 \pm 2.07^{* * * a}$ & $36.24 \pm 3^{* * a b}$ & $3.18 \pm 0.12^{* * * a b}$ \\
\hline Mel & $44.14 \pm 1.51^{* * * a}$ & $34.16 \pm 2.25^{* * a b}$ & $3.54 \pm 0.12^{* * * a b c}$ \\
\hline
\end{tabular}

Values are expressed as mean $\pm \mathrm{SD}$. *** $\mathrm{p} \leq 0.001, * * \mathrm{p} \leq 0.01, * \mathrm{p} \leq 0.05$, a: Compared to Control group, b: Compared to $\mathrm{n}-\mathrm{TiO}_{2}$ group, $\mathrm{c}$ : compared to Carnosine group.

The administration of $\mathrm{TiO}_{2}-\mathrm{NPs}$, in either doses, elevated the levels of caspase-3, TDNA and TL in comparison with the normal control $(\mathrm{p} \leq 0.001)$ as shown in Figures $1(\mathrm{~A}, \mathrm{~B}, \mathrm{C})$ and $2(\mathrm{~A}, \mathrm{~B}, \mathrm{C})$. The increase in these biomarkers was pronunced in the rats taken high doses. Oral administration of carnosine or melatonin showed significantly reduced levels of caspase-3,TDNA and TL compared with the control and $\mathrm{TiO}_{2}-\mathrm{NPs}$ intoxicated counterparts $(\mathrm{p} \leq 0.001)$, with more significant decrease in TDNA of melatonin treated group. There was significant decrease in TL levels than the TiO2-NPs intoxicated group $(\mathrm{p} \leq 0.01$, $\mathrm{p} \leq 0.001$, respectively).

Figure 3 (A, B) showed that TiO2-NPs, in either low or high doses, immunoglobulin $\mathrm{G}$ compared with normal control values $\mathrm{p} \leq 0.001$. The increase in this biomarker was prominant in rats intoxicated with high repeated doses. Treatment with carnosine or melatonin showed significant decrease serum level than TiO2-NPs intoxicated rats $p \leq 0.001$, Melatonin treated rats with low as well as high doses of TiO2-NPs showed significantly reduced level Ig G than the carnosine treated rats $p \leq 0.001$.

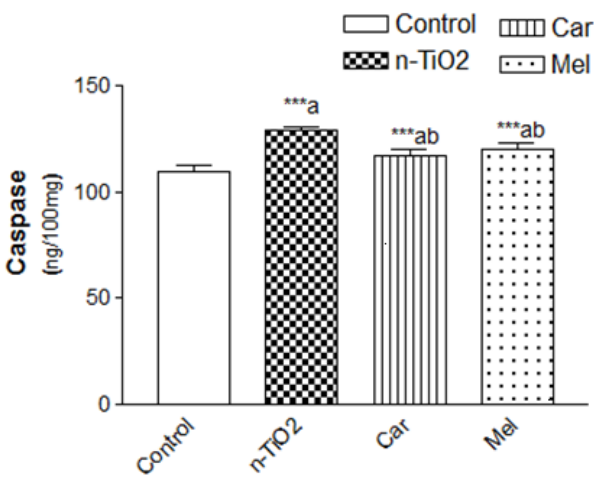

A

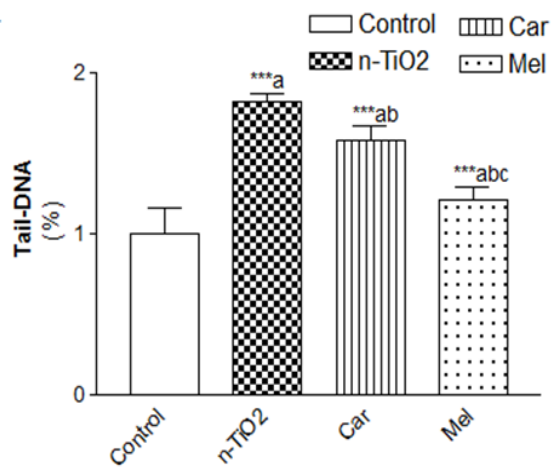

B

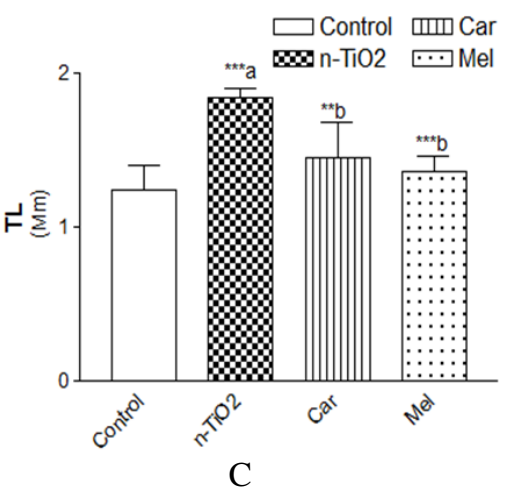

C

Figure 1 - A) Effect of carnosine and melatonin on levels of caspase-3 in rats taken low dose n- $\mathrm{TiO}_{2}$.

B) Effect of carnosine and melatonin on Tail - DNA in rats taken low dose n- $\mathrm{TiO}_{2}$.

$\mathrm{C})$ Effect of carnosine and melatonin on Tail length in rats taken low dose $\mathrm{n}-\mathrm{TiO}_{2}$. 


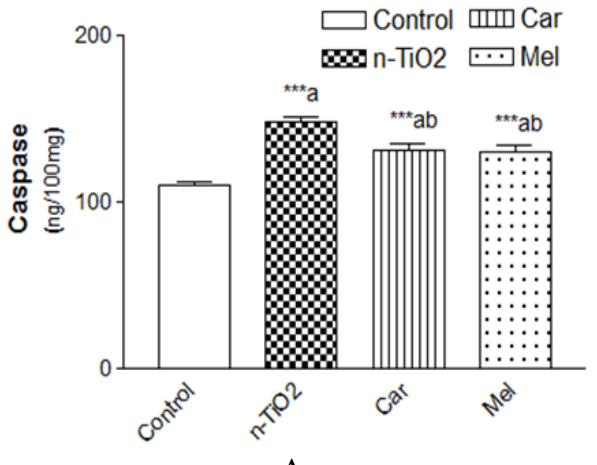

A

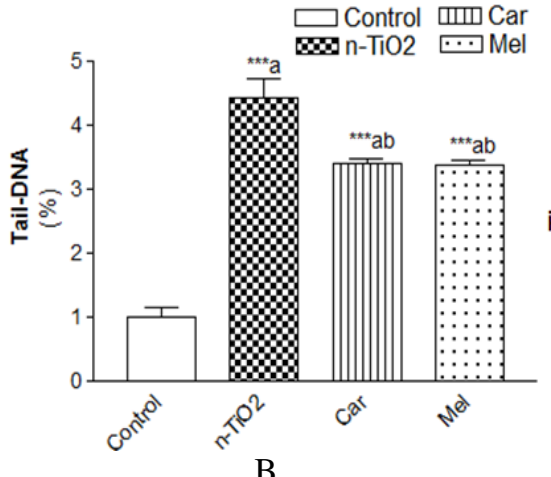

$\mathrm{B}$

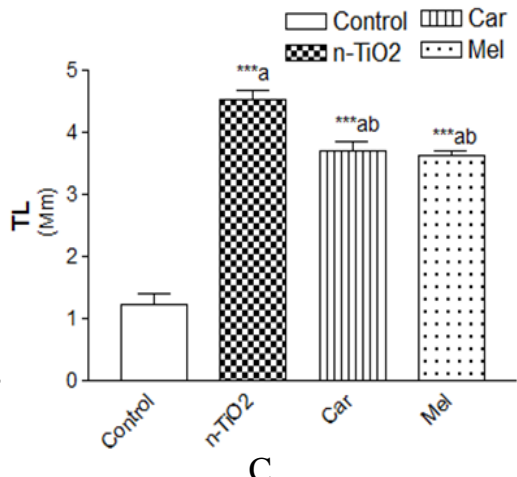

C

Figure 2 - A) Effect of carnosine and melatonin on levels of caspase-3 in rats taken high dose n- $\mathrm{TiO}_{2}$. B) Effect of carnosine and melatonin on levels of Tail-DNA in rats taken high dose $\mathrm{n}-\mathrm{TiO}_{2}$. C) Effect of carnosine and melatonin on levels of Tail length in rats taken high dose $\mathrm{n}-\mathrm{TiO}_{2}$.
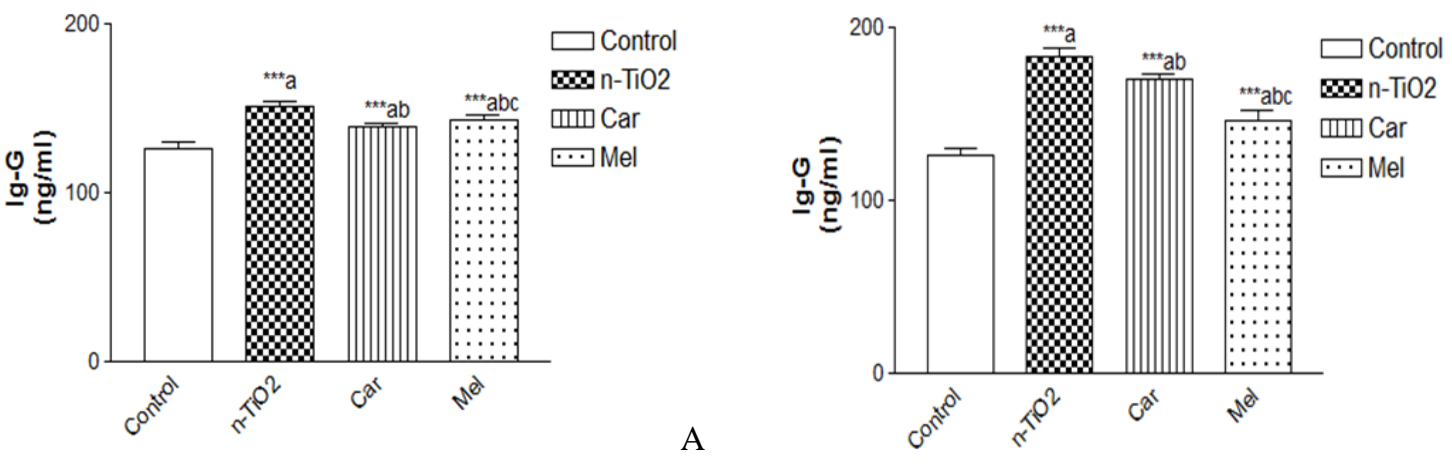

B

Figure3 - A) Effect of carnosine and melatonin on levels of $\mathrm{IgG}$ in rats taken low dose n- $\mathrm{TiO}_{2} . \mathrm{B}$ ) Effect of carnosine and melatonin on levels of $\mathrm{IgG}$ in rats taken high dose $\mathrm{n}-\mathrm{TiO}_{2}$.

As regards TNF- $\alpha$, CRP and IL-6, Figures 4 (A, $\mathrm{B}, \mathrm{C})$ and 5 (A, B, C) showed that the intake of TiO2-NPs, in either low or high repeated doses increased serum levels of these factors as compared to the control group $(\mathrm{p} \leq 0.001)$. The increase in these biomarkers was pronunced in the rats with high repeated doses of $\mathrm{TiO}_{2}$. Oral administration of carnosine or melatonin showed significantly reduced levels of the antiinflammatory markers compared with the control and TiO2-NPs intoxicated counterparts $(\mathrm{p} \leq 0.001)$.

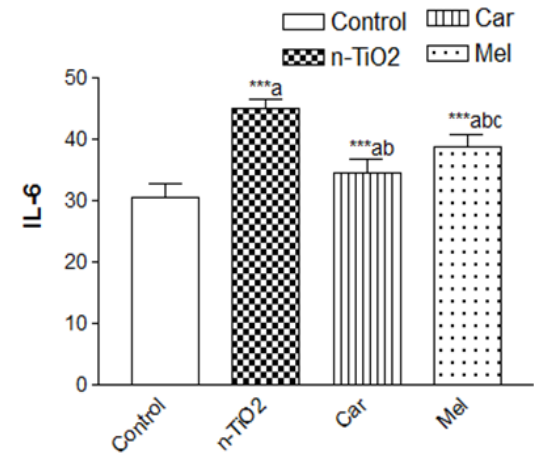

A

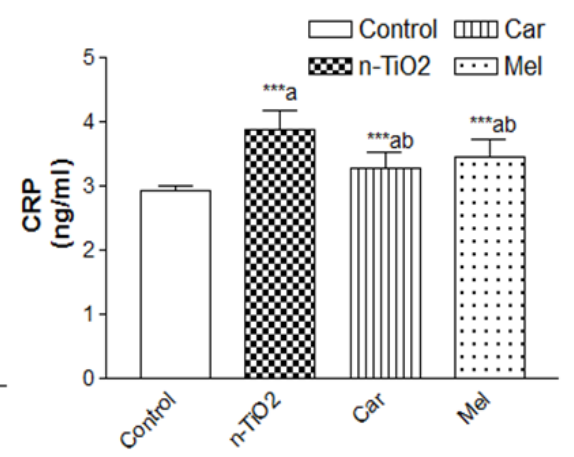

B

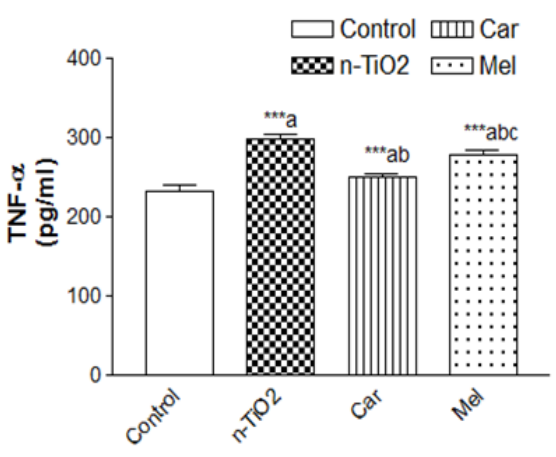

$\mathrm{C}$

Figure 4 - A)Effect of carnosine and melatonin on levels of IL-6 in rats taken low dose n- $\mathrm{TiO}_{2}$.

B) Effect of carnosine and melatonin on levels of IgG in rats taken high dose $n-\mathrm{TiO}_{2}$.

C) Effect of carnosine and melatonin on levels of TNF- $\alpha$ in rats taken low dose $n-\mathrm{TiO}_{2}$. 


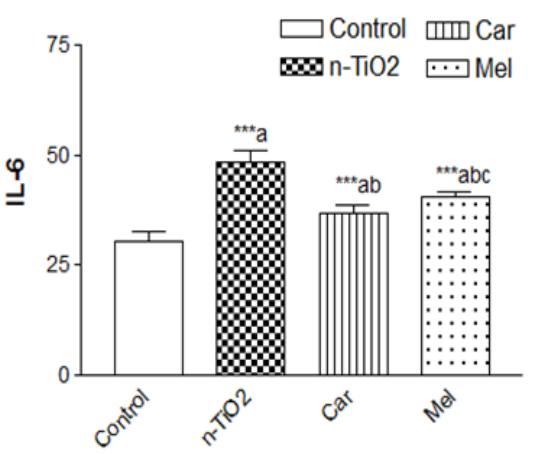

A

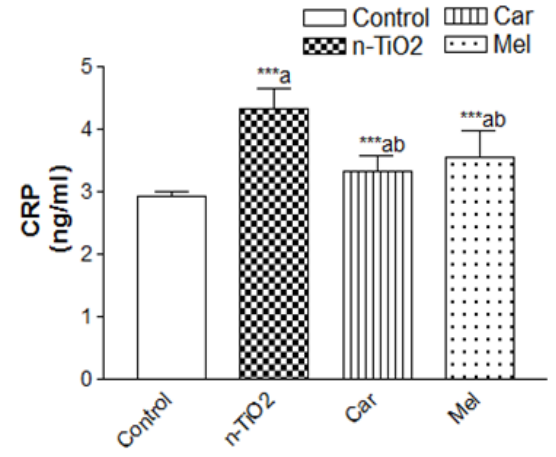

B

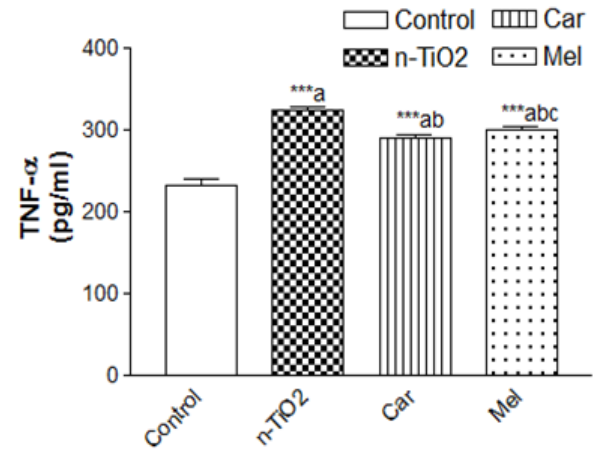

$\mathrm{C}$

Figure 5 - A) Effect of carnosine and melatonin on levels of IL-6 in rats taken high dose n- $\mathrm{TiO}_{2}$.

B) Effect of carnosine and melatonin on levels of CRP in rats taken high dose $n-\mathrm{TiO}_{2}$.

C) Effect of carnosine and melatonin on levels of TNF- $\alpha$ in rats taken high dose $n-\mathrm{TiO}_{2}$.

\section{DISCUSSION}

The present work was conducted to evaluate the effect of ingestion of $\mathrm{TiO}_{2}$ nanoparticles on cardiac tissue of the rats and the possible protective role of oral carnosine as well as oral melatonin. Results revealed no significant changes on the final weight of the ratsor their heart weight or heart/body weight (\%). Xu et al. (2013), injected once intravenous saline suspension of $\mathrm{TiO}_{2} \mathrm{NPs}$ to the rats. After the rats were sacrificed, different organs were weighed and compared to control, which showed that the spleens coefficients of $\mathrm{TiO}_{2}$ NPs treated rats were significantly increased; while, the coefficients of both liver and kidney were significantly decreased. No significant effects were observed in the coefficients of the heart, lung or brain in $\mathrm{TiO}_{2}$-NPs treated rats. Duan et al. (2010) used intragastric anatase $\mathrm{TiO}_{2}(5 \mathrm{~nm})$ in various doses in mice for continuous 30 days, which resulted decreased body weight. Other studies reported that cultured cardiomyocytes exposed to $\mathrm{TiO}_{2}$ nanoparticles concentrations larger than $0.1 \mathrm{mg} / \mathrm{mL}$ showed decrease in their growth rate (Sayes 2006; Pan et al. 2009). In another study on cardiomyocytes cell culture, exposure to 50, 100, and $150 \mu \mathrm{g} / \mathrm{mL}$ anatase or rutileTiO2 nanoparticles for two days led to decrease their viability; also, the shape of the cells rendered elongated and seemed to be detached from the surface of cell plate (Song et al. 2013). The present results concerning this aspect could be explained by short duration of exposure to the nanoparticles; also, the animals ingested the nanoparticles and were thus exposed to different metabolism and kinetics than a cell culture.
$\mathrm{TiO}_{2}$ nanomaterials have great potential in the cardiovascular system (Paunesku et al. 2003; Wu et al. 2007). They have been used as bactericidal agents in artificial heart valves (Jackson et al. 2006). Many evidences suugested that $\mathrm{TiO}_{2}$ nanoparticles taken by different routs could enter the heart causing toxicological effects, including the histopathological changes (Olmedo et al. 2002; Wang et al. 2007; Wu et al. 2009; Sheng et al. 2013). The routs of cellular uptake are either endocytosis by active uptake, or passive diffusion (Geiser et al. 2008). These studies were in agreement with the present study, which revealed that as regard cardiac functions parameters represented by myoglobin, troponinT and creatine kinase MB isozyme, the results of this study showed significant increase in these parameters, both at low and high doses of TiO2-NPs treated rats. Larsen et al. (2010) found that intraperitoneal $\mathrm{TiO}_{2}$ NPs in mice, lead to liver, kidney and cardiovascular damage indicated by the elevated serum markers of these organs. These elevation were higher in mice treated with $\mathrm{NP} \mathrm{TiO}_{2}$ than those treated with submicron-sized $\mathrm{TiO}_{2}$. Liu et al (2009) found that markers of myocardium function indicated by increased levels of aspartate aminotransferase, creatine kinase, lactate dehydrogenase, and alpha-hydroxybutyrate dehydrogenase, were observed in mice subjected to the toxic effects of NP anatase $\mathrm{TiO} 2$. The response of rat cardiac tissue exposed to $\mathrm{TiO}_{2}$ and oxidative stress (OS) was studied and compared with the rats treated with nanoparticles only and healthy rats. It was found that there was a significant increased levels of cardiac troponin I and creatine kinase-MB in the rats subjected to 
both OS conditions and $\mathrm{NP} \mathrm{TiO}_{2}$. Also, a pathological changes of myocardium was observed by Sha et al. (2013). In a study using single intravenous injection of $\mathrm{TiO}_{2} \mathrm{NPs}, 14$ days after the treatment, no significant differences in the serum levels of TBIL, ALT, AST, ALP, BUN, CREA, or CK in $\mathrm{TiO}_{2}$ NPs treated mice as compared to the control group were found. Histopathological examination revealed that $\mathrm{TiO}_{2}$ NPs could produce different organ lesions, which was dose dependent.There were pathological changes in the brain, lung, spleen, liver and kidneys. No pathological effects were observed in cardiac tissue, which could be due to delayed onset of pathological changes in the heart $(\mathrm{Xu}$ et al. 2013). Another study reported that $\mathrm{TiO}_{2}$ NPs caused abnormal pathological changes in the tissues of the heart, lung, testis, ovary, and spleen (Wang et al. 2007). The present results showed elevated levels of caspase-3, TDNA and TL. Serum levels of immunoglobulin G, TNF- $\alpha$, CRP and IL- 6 were also elevated. Some studies have shown that $\mathrm{TiO}_{2}$ nanoparticles could increase the reactive oxygen species, which in turn depleted cellular antioxidants (Long et al. 2007; Lu et al. 2008; Park et al. 2008; Wang et al. 2008; Mallik et al. 2011). Adverse biological effects exerted by NPs is thought to be caused by the oxidative stress (Donaldson et al. 2001; Gurr et al. 2005; Nel et al. 2006) and results in DNA oxidation in the heart, DNA strand breaks, inflammation and even cell necrosis (Sheng et al. 2013). Cardiac muscle is a metabolically active organ, and rich in mitochondria. Any reduction in mitochondrial membrane potential can lead to decreased energy production, which may results cytochrome c release and induce cellular apoptosis via calciumsensitive proteases, or through the activation of caspases and DNA fragmentation enzymes (Calcineurin et al. 2001). Several studies in different cell lines showed that $\mathrm{TiO}_{2} \mathrm{NP}$ could cause genotoxicity represented by DNA damage and chromosomal aberrations (Rahman et al. 2002; Wang et al. 2007; Kang et al. 2008; Xu et al. 2009; Petković et al. 2011). The exposure of peripheral human lymphocytes to $\mathrm{TiO}_{2}$ NPs can lead to the activation of DNA damage check points and accumulation of tumour suppressor protein p53 (Kang et al. 2008). In vitro and in vivo studies of different experimental models showed that nano$\mathrm{TiO}_{2}$ could cause genotoxic effects through indirect mechanisms like oxidative stress and inflammation (Driscoll et al. 1997; Xu et al. 2008; Trouiller et al. 2009; Petković et al. 2011). ROS are important signalling molecules that can affect cell proliferation, inflammation and cell death (Sha et al. 2013). Studies have confirmed the role of oxidative stress in $\mathrm{TiO}_{2}$-induced inflammation where ROS production lead to the activation of pro-inflammatory cascade including tumour necrosis factor TNF $\alpha$ (Peters et al. 2004; Xia et al. 2006; Kang et al. 2008). According to the physical and chemical properties of NPs, they can be recognized and taken up by different types of immune cells, thus trigger an inflammatory response. the expression of TNF- $\alpha$ and IL- 6 mRNA increased following the treatment with 100 and $150 \mu \mathrm{g} / \mathrm{mL}$ anatase particles. These cytokines are the molecular messengers that can influence the tissue or cell response to biomaterials (Schutte et al. 2009). Immunomodulation have been also observed in in vivo studies (Skocaj et al. 2011). Larsen et al. (2010) found increased levels of immunoglobulins $\operatorname{IgE}$ and $\mathrm{IgG} 1$ in the serum and appearance of of eosinophils, neutrophils and lymphocytes in bronchoalveolar lavage fluid after intraperitoneal $\mathrm{TiO}_{2}$ NPs intake. In the present study, oral administration of carnosine or melatonin showed significant reduced levels of all the studied parameters as they were antioxidants, thus opposed the cytotoxic effects of $\mathrm{TiO}_{2}$ - NPs due to their physicochemical properties can lead to the generation of reactive oxygen species, resulting their accumulation, which in turn, reduce the activities of antioxidant enzymes and antioxidant contents (Warheit et al. 2007; Sheng et al. 2013).

\section{CONCLUSION}

Results revealed that the severity of cytotoxic impacts of $\mathrm{TiO}_{2}$-NPs on cardiacl tissue of the rats was dose-dependent. This was pronounced from the elevation in serum cardiac function biomarkers, elevation in inflammatory mediators TNF- $\alpha$ and IL6 as well as IgG. These toxic effects were dose-dependant. The treatment with either carnitine or melatonin were effective in alleviating the deleterious effect of NPs specially in the rats exposed to low doses of the NPs. 


\section{ACKNOWLEDGMENT}

This research project was supported by a grant from the "Research center, Female Scientific and Medical Colleges Center", King Saud University.

\section{REFERENCES}

Abdelkarem HM; Faddah LM. The role of some natural antioxidants in ameliorating the toxic effects of nano titanium dioxide on bone complications in rats. IJCR 2013; 5 (12):4113-4117.

Athanassiou IK. Therapeutic Applications of Melatonin. Adv Endocrinol Metab. 2013;4(1):13-24.

Aversa S, Pellegrino S, Barberi I, Reiter R, Gitto E. Potential utility of melatonin as an antioxidant during pregnancy and in the perinatal period. J Matern Fetal Neonatal Med. 2012; 25: 207-221.

Boldyrev AA. Carnosine: new concept for the function of an old molecule. Biochemistry. 2012; 77: 313-326.

Boldyrev AA, Aldini G, Derave W. Physiology and Pathophysiology of carnosine. Physiol Rev. 2013; 93(4):1803-1845.

Buzea C, Pacheco II, Robbie K. Nanomaterials and nanoparticles: sources and toxicity. Biointerphases. 2007; 2:17-71.

Calcineurin MJ. mitochondrial membrane potential, and cardiomyocyte apoptosis. Circ Res. 2001;88:1220.

Donaldson K, Stone V, Clouter A, Renwick L, MacNee W. Ultrafine particles. Occup Environ Med. 2001; 58: 211-216.

Driscoll KE, Deyo LC, Carter JM, Howard BW, Hassenbein DG, Bertram TA. Effects of particle exposure and particle-elicited inflammatory cells on mutation in rat alveolar epithelial cells. Carcinogenesis. 1997; 18: 423-430.

Duan Y, Liu J, Ma L, Li N, Liu H, Wang J, et al. Toxicological characteristics of nanoparticulate anatase titanium dioxide in mice. Biomaterials. 2010; 31:894-899.

Galano A, Tan D, Reiter R.Melatonin as a natural ally against oxidative stress: a physicochemical examination. J Pineal Res .2011; 51: 1-16.

Geiser M, Casaulta M, Kupferschmid B, Schulz H, Semmler-Behnke M, Kreyling W. The role of macrophages in the clearance of inhaled ultrafine titanium dioxide particles. Am J Respir Cell Mol Biol. 2008; 38: 371-376.

Gitto E, Aversa S, Salpietro C, Barberi I, Arrigo T, Trimarchi $G$, et al. Pain in neonatal intensive care: role of melatonin as an analgesic antioxidant. $J$ Pineal Res. 2012; 52: 291-295.

Gurr JR, Wang AAS, Chen CH, Jan KY. Ultrafine titanium dioxide particles in the absence of photoactivation can induce oxidative damage to human bronchial epithelial cells. Toxicol. 2005; 213(1-2): 66-73

Hang L, Svanborg C, Andersson G. Determination of Interleukin 6 in Human Urine and Epithelial Cell Supernatants. Int Arch Allergy Immunol. 1994; 105: 397-403 .

Jawad H, Boccaccini AR, Ali NN, Harding SE. Assessment of cellular toxicity of $\mathrm{TiO} 2$ nanoparticles for cardiac tissue engineering applications. Nanotoxicology. 2011;5:372-380.

Jackson M, Robinson G, Ali N, Kousar Y, Mei S, Gracio J, et al. Surface engineering of artificial heart valve disks using nanostructured thin films deposited by chemical vapour deposition and sol-gel methods. $J$ Med Eng Technol. 2006; 30: 323-329.

Kang JL, Moon C, Lee HS, Lee HW, Park EM, Kim HS, et al. Comparison of the biological activity between ultrafine and fine titanium dioxide particles in RAW 264.7 cells associated with oxidative stress. J Toxicol Environ Health. Part A. 2008; 71: 478-485.

Kang SJ, Kim BM, Lee YJ, Chung HW. Titanium dioxide nanoparticles trigger p53-mediated damage response in peripheral blood lymphocytes. Environ Mol Mutagen. 2008; 49: 399-405.

Khan MJ, Maskat MY. Interaction of titanium dioxide nanoparticles with human serum albumin: A spectroscopic approach. Int J Pharm Pharm Sci. 2014; 6(3): 43-46.

Larsen ST, Roursgaard M, Jensen KA, Nielsen GD. Nano titanium dioxide particles promote allergic sensitization and lung inflammation in mice. Basic Clin Pharmacol Toxicol. 2010; 106: 114-117.

Liu H, Ma L, Zhao J, Liu J, Yan J, Ruan J, Fashui Hong. Biochemical toxicity of nano-anatase $\mathrm{TiO} 2$ particles in mice. Biol Trace Elem Res. 2009; 129 (13): $170-180$

Liu K, Lin X, Zhao j. Toxic effects of the interaction of titanium dioxide nanoparticles with chemicals or physical factors. Intern J Nanomedicine. 2013; 8: 2509-2520.

Long TC, Tajuba J, Sama P, Saleh N, Swartz C, Parker $\mathrm{J}$, et al. Nanosize titanium dioxide stimulates reactive oxygen species in brain microglia and damages neurons in vitro. Environ Health Persp. 2007; 115: $1631-1637$.

Lu N, Zhu Z, Zhao X, Tao R, Yang X, Gao Z. Nano titanium dioxide photocatalytic protein tyrosine nitration: a potential hazard of $\mathrm{TiO}_{2}$ on skin. Biochem Biophys Res Commun. 2008; 370: 675-680.

Magaye R, Zhao J. Recent progress in studies of metallic nickel and nickel-based nanoparticles' genotoxicity and carcinogenicity. Environ Toxicol Pharmacol. 2012; 34: 644-650.

Mallik A, Bryan S,Puukila S, Chen A, Khaper N. Efficacy of Pt-modified $\mathrm{TiO}_{2}$ nanoparticles in cardiac cells. Exp Clin Cardiol. 2011; 16(1): 6-10. 
Nel A, Xia T, Madler L, Li N. Toxic potential of materials at the nanolevel. Science. 2006; 311: 622-7.

OECD. OECD Guidelines for Testing of Chemicals. No 420: Acute Oral Toxicity-fixed Dose Method. Organisation for Economic Co-operation and Development, Paris 1992.

Olmedo D, Guglielmotti MB, CabriniRL. An experimental study of the dissemination of titanium and zirconium in the body. J Mater Sci Mater Med. 2002; 13(8): 793-796.

Pan Z, Lee W, Slutsky L, Clark RAF, Pernodet N, Rafailovich MH. Adverse effects of titanium dioxide nanoparticles on human dermal fibroblasts and how to protect cells. Small. 2009; 5(4) : 511-520.

Park EJ, Yi J, Chung KH, Ryu DY, Choi J, Park K et al. Oxidative stress and apoptosis induced by titanium dioxide nanoparticles in cultured BEAS-2B cells. Toxicol Lett. 2008; 180: 222-229.

Paunesku T, Rajh T, Wiederrecht G, Maser J, Vogt S, Stojićević N, et al. Biology of $\mathrm{TiO}_{2}$-oligonucleotide nanocomposites. Nat Mater. 2003; 2: 343-346.

Peters K, Unger RE, Kirkpatrick CJ, Gatti AM, Monari E. Effects of nano-scaled particles on endothelial cell function in vitro: studies on viability, proliferation and inflammation. $J$ Mater Sci Mater Med. 2004;15(4):321-325.

Petković J, Žegura B, Stevanović M, Drnovšek N, Uskoković D, Novak S, et al. DNA damage and alterations in expression of DNA damage responsive genes induced by $\mathrm{TiO} 2$ nanoparticles in human hepatoma HepG2 cells. Nanotoxicology. 2011;5:341353.

Rahman Q, Lohani M, Dopp E, Pemsel H, Jonas L, Weiss DG, et al. Evidence that ultrafine titanium dioxide induces micronuclei and apoptosis in Syrian hamster embryo fibroblasts. Environ Health Persp. 2002;110:797-800.

Robertson TA, Sanchez WY, Roberts MS. Are commercially available nanoparticles safe when applied to the skin? J Biomed Nanotechnol. 2010; 6:452-468.

Saber AT, Jensen KA, Jacobsen NR, Birkedal R, Mikkelsen L, Moller $\mathrm{P}$, et al. Inflammatory and genotoxic effects of nanoparticles designed for inclusion in paints and lacquers. Nanotoxicology. 2012; 6:453-471.

Sager TM, Kommineni C, Castranova V. Pulmonary response to intratracheal instillation of ultrafine versus fine titanium dioxide: role of particle surface area. Part Fibre Toxicol. 2008; 5(17).

Sayes CM, Wahi R, Kurian PA, Lui I, West JL, Ausman KD,et al. "Correlating nanoscale titania structure with toxicity: a cytotoxicity and inflammatory response study with human dermal fibroblasts and human lung epithelial cells," Toxicol Sci. 2006; 92(1): 174-185.
Schutte RJ, Xie L, Klitzman B, Reichert WM. "In vivo cytokine-associated responses to biomaterials". Biomaterials. 2009; 30 (2): 160-168.

Sha BY, Gao W, Wang SQ, Li W, Liang X, Xu F, et al. Nano-titanium dioxide induced cardiac injury in rat under oxidative stress. Food Chem Toxicol. 2013; 58: 280-288.

Sheng L1, Wang X, Sang X, Ze Y, Zhao X, Liu D, Gui S, Sun Q, Cheng J, Cheng Z, Hu R, Wang L, Hong F. "Cardiac oxidative damage in mice following exposure to nanoparticulate titanium dioxide". $J$ Biomed Mater Res. 1(11): 3238-3246.

Singh NP, McCoy MT, Tice RR, Schneider EL. A simple technique foe quantitation of low levels of DNA damage in individaul cells. Exp Cell Res. 1988; 175: 184-191.

Skocaj M, Filipic M, Petkovic J, Novak S.Titanium dioxide in our everyday life; is it safe? Radiol Oncol. 2011; 45(4): 227-247.

Sohaebuddin SK, Thevenot PT, Baker D, Eaton JW, Tang L. Nanomaterial cytotoxicity is composition, size, and cell type dependent. Part Fibre Toxicol. 2010; 7: 22.

Song W, Wang J, Liu M, Li P, Zhou G, Li Z, Fan Y. Titanium Dioxide Nanoparticles Induced Proinflammation of Primary Cultured Cardiac Myocytes of Rat. J Nanomater. 2013; 2013: 1-9.

Tay CY, Fang W, Setyawati MI, Chia SL,Tan KS, Hong CHL et al. Nano-hydroxyapatite and Nanotitanium Dioxide Exhibit Different Subcellular Distribution and Apoptotic Profile in Human Oral Epithelium. ACS Appl Mater Interfaces. 2014; 6 (9): 6248-6256.

Thornberry NA and Lazebnik Y. Caspases: enemies within. Science. 1998; 281:1312-1316.

Trouiller B, Reliene R, Westbrook A, Solaimani P, Schiestl RH. Titanium dioxide nanoparticles induce DNA damage and genetic instability in vivo in mice. Cancer Res. 2009; 69: 8784-8789.

Varghese O, Paulose M, LaTempa T, Grimes C. Highrate solar photocatalytic conversion of $\mathrm{CO}_{2}$ and water vapor to hydrocarbon fuels. Nano Lett. 2009; 9: 731737.

Wang J, Zhou G, Chen C, Yu H, Wang T, Ma Y, et al. Acute toxicity and biodistribution of different sized titanium dioxide particles in mice after oral administration. Toxicol Lett. 2007; 168( 2): 176-185.

Wang JJ, Sanderson BJS, Wang H. Cyto- and genotoxicity of ultrafine $\mathrm{TiO}_{2}$ particles in cultured human lymphoblastoid cells. Mutat Res-Gen Tox En. 2007; 628: 99-106.

Wang JX, Chen CY, Liu Y, Jiao F, Li W, Lao F, et al. Potential neurological lesion after nasal instillation of $\mathrm{TiO} 2$ nanoparticles in the anatase and rutile crystal phases. Toxicol Lett. 2008; 183: 72-80. 
Warheit DB, Webb TR, Reed KL, Frerichs S, Sayes CM. Pulmonary toxicity study in rats with three forms of ultrafine-TiO2 particles: Differential responses related to surface properties. Toxicol. 2007; 230: 90-104.

Wu G, Nishikawa T, Ohtani B, Chen A. Synthesis and characterization of carbon-doped $\mathrm{TiO}_{2}$ nanostructures with enhanced visible light response. Chem Mater. 2007; 19: 4530-4537.

Wu J, Liu W, Xue C, Zhou S, Lan F, Bi L, et al. Toxicity and penetration of $\mathrm{TiO}_{2}$ nanoparticles in hairless mice and porcine skin after subchronic dermal exposure. Toxicol Lett. 2009; 191(1): 1-8.

Zhao J, Bowman L, Zhang X, Vallyathan V, Young $\mathrm{SH}$,Castranova $\mathrm{V}$ et al Titanium dioxide $\left(\mathrm{TiO}_{2}\right)$ nanoparticles induce JB6 cell apoptosis through activation of the caspase-8/Bid and mitochondrial pathways. J Toxicol Environ Health A. 2009; 72: 1141-1149.

Zhao J, Castranova V. Toxicology6of nanomaterials used in nanomedicine. Toxicol Environ Health BCrit Rev. 2011; 14: 593-632.
Zhu Y, Eaton JW, Li C. Titanium dioxide (TiO2) nanoparticles preferentially induce cell death in transformed cells in a Bak/Bax-independent fashion. PLoS ONE .2012;7: e5060.

Xia T, Kovochich M, Brant J,_Hotze M, Sempf J, Oberley $\mathrm{T}$, et al. Comparison of the abilities of ambient and manufactured nanoparticles to induce cellular toxicity according to an oxidative stress paradigm. Nano Lett. 2006; 6(8): 1794-1807.

$\mathrm{Xu}$ A, Chai YF, Nohmi T, Hei TK. Genotoxic responses to titanium dioxide nanoparticles and fullerene in gpt delta transgenic MEF cells. Part Fibre Toxicol. 2009; 6:3.

$\mathrm{Xu}$ J, Shi H, Ruth M, Yu H, Lazar Land Yang C. Acute Toxicity of Intravenously Administered Titanium Dioxide Nanoparticles in Mice. PLoS ONE.2013;8(8): e70618.

Received: January 12, 2015; Accepted: April 19, 2015 